\title{
Long Term Hydrological Effects of Bioretention on Expressway Service Area
}

\author{
Junkui Pan*, Jiawei Liu, Guoping Hu, Jiamei Su, Guangyi Qin \\ School of Civil and Transportation Engineering, Henan University of Urban Construction, Longxiang Avenue, \\ Xinhua District, Pingdingshan 467000, China
}

Received: 7 May 2021

Accepted: 18 September 2021

\begin{abstract}
Taking an expressway service area as the study object, based on the SWMM and VADOSE/W models, the long-term water balance of exfiltration type bioretention (ZR) and anti-seepage type bioretention (ZF) were quantified, and the performance of bioretention on the long-term hydrological effects of the service area was studied. The results show that the ZR can significantly increase the annual underground discharge ratio compared with ZF, thereby reducing the underdrain outflow ratio, but has little effect on the overflow ratio and evapotranspiration ratio. ZR can significantly improve the hydrological balance of the service area, and increase the annual runoff control rate by $48.21 \%$, and the utilization rate of rainwater resources in the service area can reach $73.47 \%$ by the combination of $\mathrm{ZF}$ and reservoir. For typical annual rainfall events, the average values of runoff reduction rate, runoff peak reduction rate and runoff delay of traditional service area were $59.45 \%, 57.17 \%$ and $5.19 \mathrm{~h}$ respectively, those of service area with ZR were $91.56 \%, 95.22 \%$ and $20.55 \mathrm{~h}$ respectively, and those of service area with ZF were $68.59 \%, 86.67 \%$ and $15.22 \mathrm{~h}$ respectively. ZR and ZF can both effectively improve the rainfall regulation ability of the service area, and the performance of ZR is relatively better. Furthermore, the correlation between runoff characteristics and rainfall characteristics for three types of service areas was analyzed, which can provide a reference for forecasting and controlling rainwater runoff in the service area.
\end{abstract}

Keywords: bioretention, hydrological performance, expressway service area, SWMM, VADOSE/W

\section{Introduction}

With the rapid development of China's expressway network, the number of service areas as important ancillary facilities of expressway has also increased significantly [1]. However, impervious areas such as roads, roofs, parking lots, and refueling areas in the

*e-mail: 15303950218@163.com service area can account for over $70 \%$ of the total area of the service area, which leads to reduced rainfall infiltration and destruction of the natural hydrological balance, as well as many problems regarding rainwater discharge [2-3]. At the same time, due to the concentration of people and motor vehicles in the service area, rainwater runoff usually contains a lot of pollutants, including suspended solids, organic matter, heavy metals, nitrogen and phosphorus nutrients, oil and grease, etc., which will have serious adverse 
impacts on the regional water environment [4-5]. In addition, the expressway service area is generally far away from the urban municipal water supply network, while toilet flushing, car washing, greening, and road watering in the service area need a lot of water, but a lot of rainwater is discharged without effective utilization, leading to the loss of rainwater resources [6].

With the deterioration of global water environment, a variety of strategies have been developed to improve the rainwater problem over the last several decades, among them, bioretention is a promising measure integrating landscape, runoff control and water purification. Bioretention is usually composed of 150 300 mm aquifer, 25 80 mm mulch layer, 300 700 $\mathrm{mm}$ planting soil layer, $200 \sim 500 \mathrm{~mm}$ filler layer, 150 300 $\mathrm{mm}$ gravel layer, and vegetation, and its design scale is generally $5 \% \sim 10 \%$ of the catchment area [7-9]. According to factors such as the groundwater level, soil permeability, construction location and application scope, bioretention can be divided into two types: antiseepage type and exfiltration type [10]. The bottom of the anti-seepage bioretention is set with an impermeable membrane, and the bottom of the gravel layer needs to be equipped with an underdrain to strengthen drainage. For exfiltration type bioretention, there is no waterproof treatment, and the treated runoff can penetrate into the ground, but when the permeability coefficient of in-situ soil is lower than $1.27 \mathrm{~cm} / \mathrm{h}$, an underdrain should also be set. Bioretention can simulate the hydrologic conditions prior to regional development by slowly exfiltrating water to the surrounding soil and by evapotranspiration [11]. Moreover, bioretention can utilize the chemical, biological, and physical properties of plants, microbes, and soils to remove contaminants from rainwater runoff, thereby improving the quality of runoff water [12]. At present, bioretention plays a significant role in the treatment of urban stormwater runoff [13].

In recent years, some scholars have studied the hydrological performance of bioretention by laboratory and field experiments. Debusk [14], Pan [15], Winston [16], and Xia [17] all proved that biolretention can regulate rainfall runoff and improve the regional hydrological cycle, and Gülbaz [18], Li [19], Gao [20], and Liu [21] all showed that the hydrological performance of bioretention is mainly affected by regional rainfall characteristics and design parameters. However, the current research and application of bioretention are mostly concentrated in urban areas [2224], while the application of bioretention in expressway service areas with serious rainwater problems still lacks systematic research and theoretical support. In addition, the current studies on the hydrological performance of bioretention is mostly based on shortterm design rainfall events, but long-term hydrological effects are also an important indicator to evaluate the regional hydrological environment. However, there are few studies on the quantification of long-term water balance elements of bioretention and the performance of bioretention on the long-term hydrological effect of the region.

Numerical model can provide support for the planning, design and research of bioretention. At present, only a few hydrologic models, such as RECARGA, HYDRUS-1D, SWMM, and SUSTAIN, etc., are available to simulate strom-water runoff management of bioretention. Among them, the RECARGA model uses the Green-Ampt equation to represent infiltration, which is specifically designed for bioretention, but it does not consider the structural layering of the planting soil and the filler layer, and at the same time, it is impossible to arbitrarily specify the hydraulic parameters of the medium, which limits its wide application [25]. The HYDRUS-1D model adopts Richards' equation to simulate the water movement in soil, but it is a one-dimensional model, ignoring the lateral diffusion of soil water, and it is not suitable for the bioretention with internal water storage area and to simulate the horizontal exfiltration to in-situ soil [26]. SWMM and SUSTAIN are used to simulate the runoff process and plan the LID (low impact development) measures of the entire study region, which simplify the structural design parameters and water infiltration process of bioretention, and have obvious shortcomings in the study of bioretention alone $[2,27]$. VADOSE/W is a two-dimensional numerical model to simulate soil evaporation, seepage, groundwater change and plant transpiration under saturated-unsaturated condition, coupling Richards' equation and atmospheric boundary conditions to calculate soil water movement and surface ponding process [28]. Gao [11] used VADOSE/W model to study the ponding and outflow process of road bioretention, and proved that VADOSE/W could effectively simulate the hydrological effects of twodimensional bioretention.

In this paper, SWMM and VADOSE/W models are used to achieve three main research objectives: 1) quantifying the water balance elements of exfiltration type and anti-seepage type bioretention; 2) studying the long-term hydrological performance of exfiltration type and anti-seepage type bioretention on the expressway service area; 3) analyzing the correlation between rainfall characteristics and runoff characteristics on expressway service area, so as to provide a theoretical reference for the future application of bioretention in expressway service area.

\section{Study Area}

An expressway service area in Sichuan, China, was used as the study area. The left and right sides of the service area are symmetrically arranged, with a total area of $18503 \mathrm{~m}^{2}$ on one side, and the impervious area is composed of a roof, parking lot, traffic road, and fueling area, which together account for $88.3 \%$ of the total area. The service area is higher in the northeast 


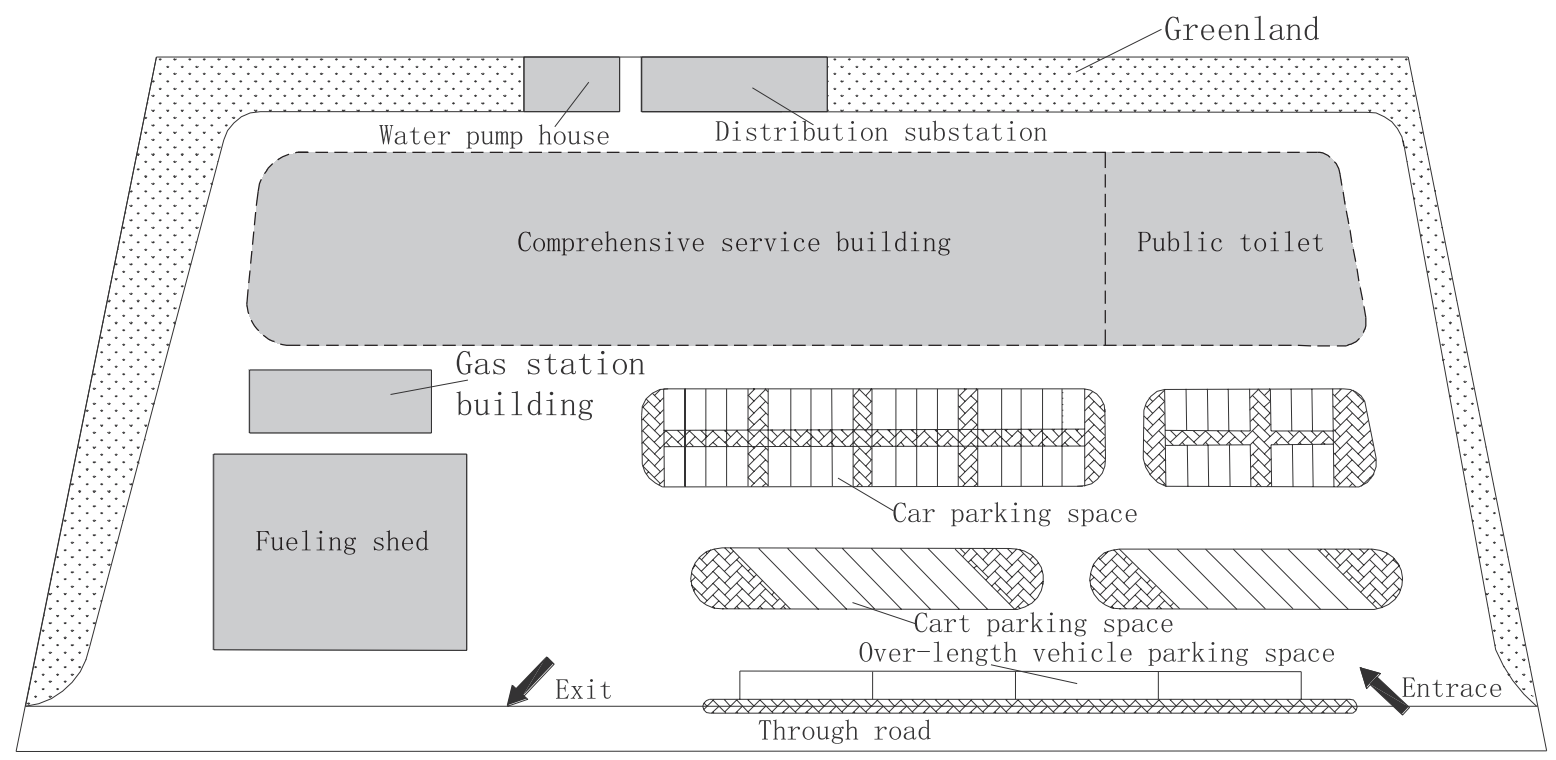

Fig.1. Layout of the expressway service area used in this study.

and lower in the southwest, with a slope of $2 \%$. The rainwater in the service area is discharged into the rainwater inlet along the vertical and horizontal slope, and then discharged into the roadside ditch through the rainwater pipeline. The hardening area of the site is large, and the comprehensive runoff coefficient is high, which makes the site runoff discharge pressure large, and there is a certain risk of waterlogging, and a large amount of rainwater is discharged without effective use, resulting in the waste of rainwater resources. The plane layout of one side of the service area is shown in Fig. 1.

Fig. 2a) shows the distribution of annual rainfall in the study area from 1951 to 2013. The most arid year in the study area is 1958 , with a total rainfall of $738 \mathrm{~mm}$, while the most abundant rainfall year is 2011, with a total rainfall of $1513 \mathrm{~mm}$. The average annual rainfall in the study area from 1951 to 2013 is $1090 \mathrm{~mm}$, and the rainfall in 2010 is $1045 \mathrm{~mm}$, which is close to the average annual rainfall. Therefore, the rainfall data in 2010 were used as the typical annual design rainfall for the study area.

The hourly rainfall distribution of the study area in 2010 is shown in Fig. 2b). The total number of rainfall events in 2010 is 113 , and the rainfall is unevenly distributed in the year, of which the rainfall mainly distributes from April to September, accounting for $85 \%$ of the total annual rainfall, and most of the rainfall events in the study area are light rain less than $10 \mathrm{~mm}$, reaching 80 , accounting for more than $70 \%$ of the total rainfall events.

The distribution of daily temperature, water evaporation, relative humidity, and average wind speed in the study area in 2010 are shown in Fig. 2(c-f), espectively. The daily maximum temperature range of the study area in 2010 is $6.5 \sim 40.6^{\circ} \mathrm{C}$, while the daily minimum temperature range is $0.8 \sim 30.1^{\circ} \mathrm{C}$, and the high temperature is mostly concentrated in July and August. The annual temperature in the study area is basically above $0^{\circ} \mathrm{C}$, so the annual water basically falls in the form of rain. The daily evaporation of the study area in 2010 ranges from $0.3 \mathrm{~mm} / \mathrm{d}$ to $7 \mathrm{~mm} / \mathrm{d}$ with an annual potential evaporation of $655 \mathrm{~mm}$, and the water evaporation changes with months into a partial normal distribution, and the maximum months is July and August, in which the average daily evaporation reached $3.18 \mathrm{~mm}$ and $4.24 \mathrm{~mm}$, respectively. The daily average relative humidity of the study area in 2010 ranged from $46 \%$ to $97 \%$, and the annual average relative humidity was $77.56 \%$. Compared with the annual average relative humidity of different regions in China ( $38 \%$ to $82 \%$ ), the study area belongs to the region with relatively high air humidity. The average daily wind speed of the study area in 2010 is $0.2 \sim 3.4 \mathrm{~mm} / \mathrm{s}$, and the average annual wind speed is $1.31 \mathrm{~mm} / \mathrm{s}$, and the wind speed distribution is relatively uniform.

\section{Methodology}

SWMM and VADOSE/W were applied together to study the hydrologic performance of bioretention in the expressway service area. Firstly, the SWMM model made a reasonable generalization of the study area, and hourly rainfall and daily evaporation data from 2010 were used to generate runoff-time data. Subsequently, the daily temperature, water evaporation, relative humidity, average wind speed, and generated runoff data in the study area were applied to the VADOSE/W model to obtain the long term hydrological response of bioretention. Finally, the influence of bioretention on hydrological effect of expressway service area was analyzed. 

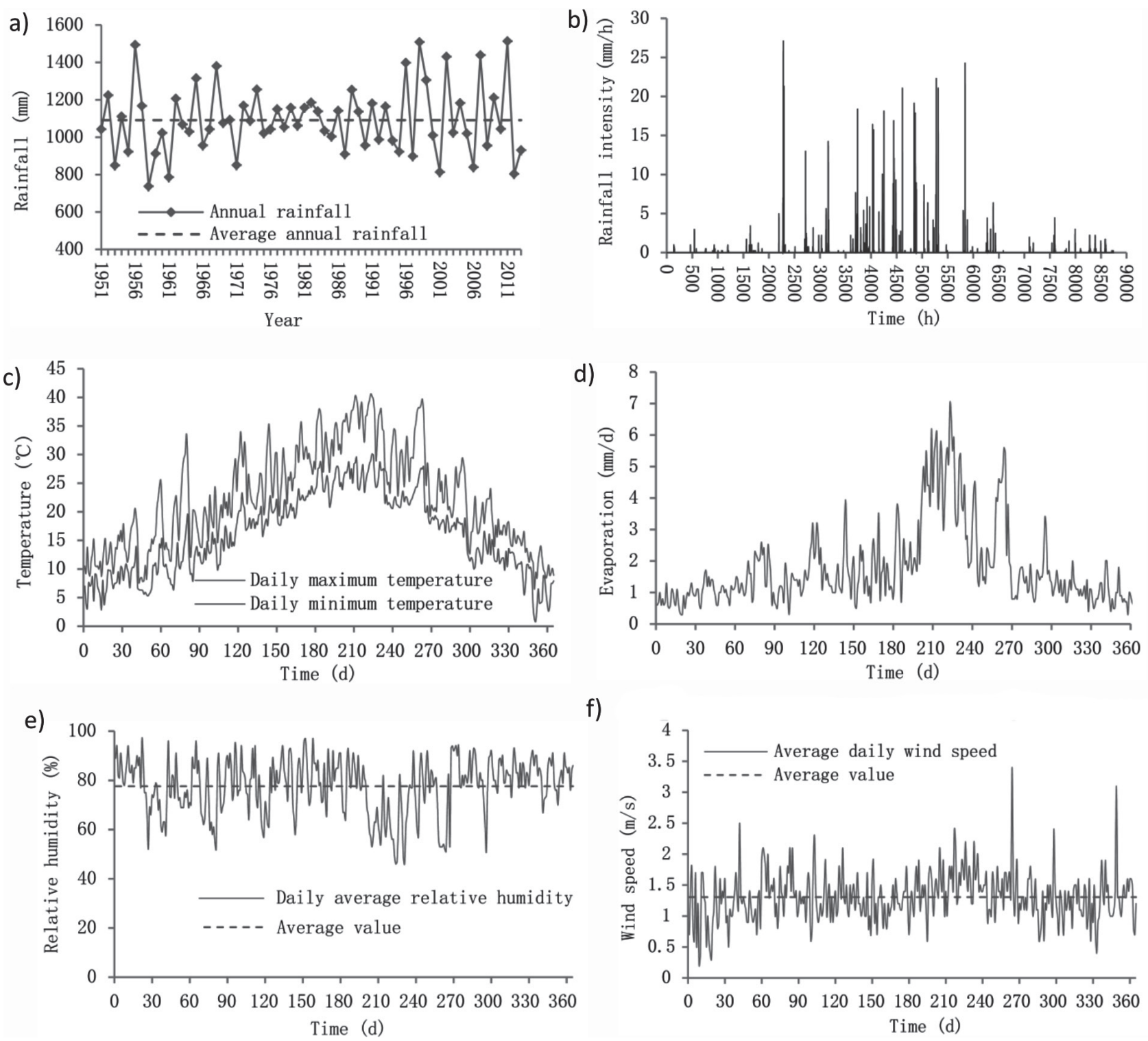

f)

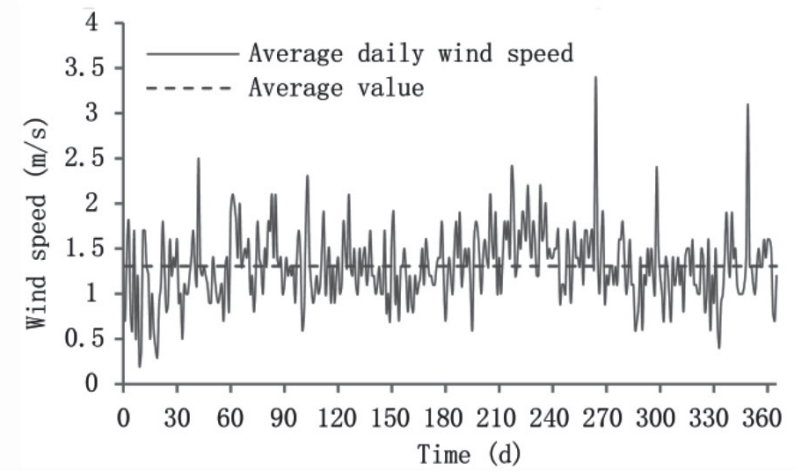

Fig. 2. Distribution of rainfall, temperature, evaporation, relative humidity, and wind speed in the study area: a) annual rainfall in the study area from 1951 to 2013, b) hourly rainfall distribution in the study area in 2010, and c), d), e), and f) distribution of daily temperature, evaporation, relative humidity and average wind speed in the study area in 2010, respectively.

\section{Surface Runoff Simulation in Expressway Service Area}

\section{Generalization of Expressway Service Area Based on SWMM Model}

When the SWMM model is used to simulate the surface runoff of the study area, it is necessary to generalize the site of the study area. When generalizing, not only the differences of the regional characteristics, but also the distribution of drainage pipes should be considered. As an expressway service area is relatively small and the pipeline distance is relatively short, and the runoff path of the service area is single, the influence of the drainage pipeline can be ignored, and the service area can be generalized into a sub-catchment area and an outlet node.

\section{SWMM Model Parameters}

SWMM model parameters are mainly divided into hydrological and hydraulic parameters, water quality parameters and LID parameters. This paper mainly uses SWMM to simulate surface runoff, so it mainly involves hydrological and hydraulic parameters, including area, width, slope, percent of impervious area, Manning's roughness of impervious area and pervious area, depression storage of impervious area and pervious area, percent of impervious area with no depression storage, and infiltration model parameters. Horton model is mainly used to simulate the rainfall infiltration process in this study, and the input parameters include the maximum infiltration rate, minimum infiltration rate, decay constant and drying time. 
Table 1. Main parameter values of SWMM model surface runoff module.

\begin{tabular}{|c|c|c|c|}
\hline Parameter types & \multirow{2}{*}{\multicolumn{2}{|c|}{$\begin{array}{c}\text { Parameter name } \\
\text { Area }\left(\mathrm{m}^{2}\right)\end{array}$}} & Values \\
\hline \multirow{3}{*}{ Deterministic parameters } & & & 19858.3 \\
\hline & \multicolumn{2}{|r|}{ Slope (\%) } & 2.0 \\
\hline & & 88.5 \\
\hline \multirow{10}{*}{$\begin{array}{l}\text { Nondeterministic } \\
\text { parameters }\end{array}$} & \multirow{3}{*}{$\begin{array}{l}\text { Manning's roughness } \\
\text { coefficient }\end{array}$} & Width $(\mathrm{m})$ & 112.0 \\
\hline & & Impervious area Manning's roughness & 0.02 \\
\hline & & Pervious area Manning's roughness & 0.35 \\
\hline & & Impervious area depression storage $(\mathrm{mm})$ & 2.5 \\
\hline & Surface depression & Pervious area depression storage $(\mathrm{mm})$ & 6.0 \\
\hline & & $\begin{array}{c}\text { Percent of impervious area with no depression } \\
\text { storage (\%) }\end{array}$ & 15.0 \\
\hline & & Maximum infiltration rate $(\mathrm{mm} / \mathrm{h})$ & 76.2 \\
\hline & Horton model & Minimum infiltration rate $(\mathrm{mm} / \mathrm{h})$ & 3.8 \\
\hline & HOH & Attenuation constant $\left(\mathrm{h}^{-1}\right)$ & 4.5 \\
\hline & & Drying time (d) & 8.0 \\
\hline
\end{tabular}

SWMM model parameters can be divided into deterministic parameters and nondeterministic parameters according to their obtain methods. Among them, the area, slope and percent of impervious area are deterministic parameters, and the rest are nondeterministic parameters. In this study, the deterministic parameters were obtained directly through the relevant drawings and field monitoring, while the nondeterministic parameters were obtained according to the typical range of parameter values given by the SWMM user manual and related literature [29-31], and the runoff coefficient method proposed by Liu [32] was used to calibrate and verify the nondeterministic parameters. The main parameter values of SWMM surface runoff module are shown in Table 1.

\section{Simulation of Bioretention Hydrology \\ Water Balance Elements of Bioretention}

The cross section and flow path of bioretention are shown in Fig. 3. When the rainwater runoff of the catchment area flows into the bioretention, the rainwater will first infiltrate into the bioretention medium. If the runoff intensity is greater than the surface infiltration capacity of bioretention, the aquifer begins ponding water, and when the ponding water exceeds the storage capacity of the aquifer, the overflow began to occur. Part of the water infiltrated into bioretention is stored in the medium pores, which can be diffused into the atmosphere through evapotranspiration after

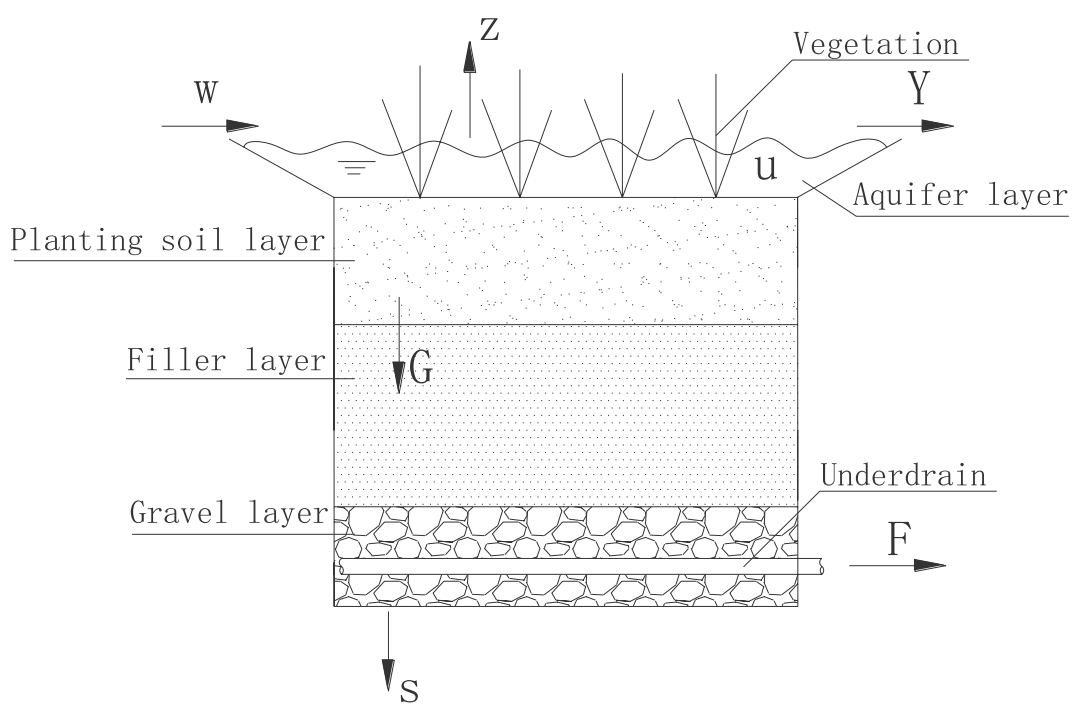

Fig. 3. The cross section and flow path of bioretention. 
the rainfall is over, and part of the water will exfiltrate into the surrounding soil. When the water level at the bottom of the bioretention gravel layer reaches the underdrain, then the underdrain begins to outflow. Therefore, in any period of time, there is a certain water balance relationship among the hydrological elements of bioretention, as shown in Equation (1).

When the service area needs to recycle the rainwater, or in order to prevent the water from affecting the safety of buildings and subgrade when bioretention is set beside the buildings or roads, the anti-seepage bioretention can be used, and the relationship between the hydrological elements of bioretention is shown in Equation (2).

$$
\begin{gathered}
W=S+Z+U+G+F+Y \\
W=Z+U+G+F+Y
\end{gathered}
$$

where $W$ is the runoff volume, $S$ is the water volume exfiltrating to surrounding soil; $Z$ is evapotranspiration water volume; $U$ is the ponding water volume in the aquifer; $G$ is the water volume stored in medium pores; $F$ is water volume of underdrain discharge; $Y$ is overflow water volume.

\section{Governing Equation of Soil Water Movement}

The upper side of bioretention media is in direct contact with the air, and the lower boundary is at a certain distance from the groundwater, belonging to variably saturated soil, the water flow of which can be described by Richards' equation, as shown in Equation (3).

$$
\frac{\partial \theta}{\partial t}=\frac{\partial}{\partial x}\left[k(\theta) \frac{\partial h}{\partial x}\right]+\frac{\partial}{\partial z}\left[k(\theta) \frac{\partial h}{\partial z}\right]+\frac{\partial k(\theta)}{\partial z}-S(x, z, t)
$$

where $h$ is the soil negative pressure head (mm); $k(\theta)$ is the hydraulic conductivity $(\mathrm{mm} / \mathrm{h}) ; \theta$ is the soil volumetric moisture content $\left(\mathrm{mm}^{3} / \mathrm{mm}^{3}\right) ; x$ and $z$ is the horizontal and vertical position, respectively (mm); $S(x, z, t)$ is the source and sink terms, such as evapotranspiration $(\mathrm{mm} / \mathrm{h})$; and $t$ is the time $(\mathrm{h})$.

When $h \geq 0$, the soil is saturated, and $\theta$ and $k(\theta)$ in Equation (3) are both fixed values, which are the saturated soil water content and the saturated soil hydraulic conductivity, respectively. When $h<0$, the soil is in an unsaturated state, and $\theta$ and $k(\theta)$ are variable values, which can be described by the soil water characteristic curve (Equation 4) and the hydraulic conductivity curve (Equation 5), respectively, proposed by van Genuchten.

$$
\theta(h)=\left\{\begin{array}{cc}
\theta_{r}+\frac{\theta_{s}-\theta_{r}}{\left[1+|a h|^{n}\right]^{m}} & (h<0) \\
\theta_{s} & (h \geq 0)
\end{array}\right.
$$

$$
K(\theta)=\left\{\begin{array}{cc}
K_{s} S_{e}^{1 / 2}\left[1-\left(1-S_{e}^{1 / m}\right)^{m}\right]^{2} & (h<0) \\
K_{s} & (h \geq 0)
\end{array}\right.
$$

...where $\theta_{r}$ is the residual soil water content $\left(\mathrm{mm}^{3} /\right.$ $\left.\mathrm{mm}^{3}\right) ; \theta_{s}$ is the saturated soil water content $\left(\mathrm{mm}^{3} / \mathrm{mm}^{3}\right)$; $a, n$, and $m$ are the van Genuchten parameters, and $m=1-1 / n ; K_{s}$ is the saturated hydraulic conductivity $(\mathrm{mm} / \mathrm{h}) ; S_{e}$ is the effective saturation of soil water, and $S_{e}=\left(\theta-\theta_{r}\right) /\left(\theta_{s}-\theta_{r}\right)$.

In the VADOSE/W model, if the potential evaporation data of the study area were monitored, then the actual evaporative flux in the model is determined based on the current time steps potential evaporation value according to the Equation (6).

$$
E=E_{p}\left\{\frac{h_{r}-\frac{P_{\text {vsat } \cdot a i r}}{P_{v s a t \cdot s o i l}} h_{a}}{1-\frac{P_{\text {vsat:air }}}{P_{\text {vsat } \text { soil }}} h_{a}}\right\}
$$

where $E_{p}$ is the potential evaporation $(\mathrm{mm} / \mathrm{d}) ; P_{\text {vsat air }}$, and $P_{v s a t \text { soil }}$ are the saturated vapor pressure of soil and air, respectively $(\mathrm{kPa}) ; h_{r}$ and $h_{a}$ are the relative humidity of soil surface and air, respectively.

When the soil surface is covered with vegetation, transpiration is the main way for soil water to diffuse into the atmosphere. Generally, the transpiration of plants can occur at any part of the plant surface, but the transpiration of leaves is the largest, accounting for more than $90 \%$ of the total transpiration [33]. The transpiration of plant is described by Equation (7).

$$
T_{a}=\frac{2 T_{p}}{R_{t}}\left(1-\frac{R_{n}}{R_{t}}\right) A_{n} f_{P M L}
$$

where $T_{p}$ is the plant potential transpiration when soil is saturated $(\mathrm{mm} / \mathrm{d})$, and $T_{p}=E_{p}(-0.21+0.7 \sqrt{L A I}) ; L A I$ is the leaf area index; $R_{t}$ is the total thickness of root zone (mm); $R_{n}$ is the depth to the node in question (mm); $A_{n}$ is the nodal contributing area of the node in question $\left(\mathrm{mm}^{2}\right), f_{P M L}$ is the plant moisture limiting function value at the current nodal soil negative pore water pressure $(\mathrm{MPa})$, and $f_{P M L}=1 /\left[1+(h / 0.5)^{3}\right]$.

\section{Design Parameters of Bioretention}

In this study, the VADOSE/W model was used to simulate the hydrological performance of two types of bioretention: exfiltration type (ZR) and anti-seepage type (ZF). The scale of the two types of bioretention are both $10 \%$ of the total area of the service area, and the aquifer depth are both $23 \mathrm{~cm}$, and the thickness of the planting soil layer and filler layer are both $50 \mathrm{~cm}$, and the gravel layer thickness is $30 \mathrm{~cm}$. An underdrain with a diameter of $5 \mathrm{~cm}$ is set in the middle of the gravel layer to form an internal water storage 
Table 2. Hydraulic parameters of bioretention media and surrounding soil.

\begin{tabular}{|c|c|c|c|c|c|c|}
\hline Soil type & $K_{s}\left(\mathrm{~cm} \cdot \mathrm{h}^{-1}\right)$ & $\theta_{r}\left(\mathrm{~cm}^{3} \cdot \mathrm{cm}^{-3}\right)$ & $\theta_{s}\left(\mathrm{~cm}^{3} \cdot \mathrm{cm}^{-3}\right)$ & $a\left(\mathrm{~cm}^{-1}\right)$ & $n$ & $m$ \\
\hline \multicolumn{7}{|c|}{ Bioretention media } \\
\hline Planting soil & 5.04 & 0.058 & 0.408 & 0.057 & 2.000 & 0.500 \\
\hline Filler layer & 163.00 & 0.046 & 0.445 & 0.153 & 2.641 & 0.621 \\
\hline Gravel layer & 360.00 & 0.025 & 0.400 & 0.200 & 4.410 & 0.773 \\
\hline \multicolumn{7}{|c|}{ Surrounding soil } \\
\hline Clay & 0.616 & 0.098 & 0.459 & 0.015 & 1.253 & 0.202 \\
\hline
\end{tabular}

area with a height of $15 \mathrm{~cm}$. For ZR, a surrounding soil layer with the thickness of $100 \mathrm{~cm}$ is established around the bioretention, and the soil type is clay. The vegetation of bioretention is Ophiopogon japonicus (a perennial evergreen herb), which is commonly used in landscaping. The leaf area index is 5.12 [34], and the root growth depth is $30 \mathrm{~cm}$.

\section{Soil Hydraulic Parameters}

The soil hydraulic parameters of planting soil layer, filter layer and gravel layer all adopt the datas which are verified when studying the influence of bioretention parameters on the regulation effect of road runoff [11], and the surrounding soil of ZR use the clay hydraulic parameters that come from the VADOSE/W model, as shown in Table 2.

\section{Results and Discussion}

\section{Analysis of Bioretention Annual Water Balance}

As shown in Fig. 4(a-b), after a year of operation, for $\mathrm{ZF}$, underdrain discharge is the main rainwater drainage path, accounting for $93.56 \%$ of the total runoff volume, while ZR can significantly increase the underground recharge ratio, accounting for $59.30 \%$, thus reducing the underdrain discharge, but has little effect on the overflow (both accounting for $2.0 \%$ for $\mathrm{ZR}$ and $\mathrm{ZF}$ ) and evapotranspiration (both accounting for $5.34 \%$ for ZR and ZF). The evapotranspiration also play an important role in the hydrology efficiency of bioretention in the long run, which can provide a greater available soil water storage capacity for the next rainfall. In addition, the medium retention ratio of $\mathrm{ZF}$ is $0.6 \%$ higher than that of ZR (accounting for $0.25 \%$ and $0.85 \%$ for $\mathrm{ZR}$ and $\mathrm{ZF}$, respectively), which is due to the fact that the rainwater detained in the lower part of the underdrain of ZF cannot be discharged.

Influence of Bioretention on Long Term Hydrology of Expressway Service Area

As can be seen from Fig. 5, in 2010, the total surface runoff volume, total groundwater recharge volume, and total evapotranspiration volume of the traditional expressway service area are 790.1, 103.6, and 151.7 $\mathrm{mm}$, respectively, accounting for $75.60 \%$, 9.91\%, and $14.51 \%$ of total rainfall, respectively. So for the traditional expressway service area based on hardened surface, most of the annual rainfall is discharged in the form of surface runoff, while the ratio of

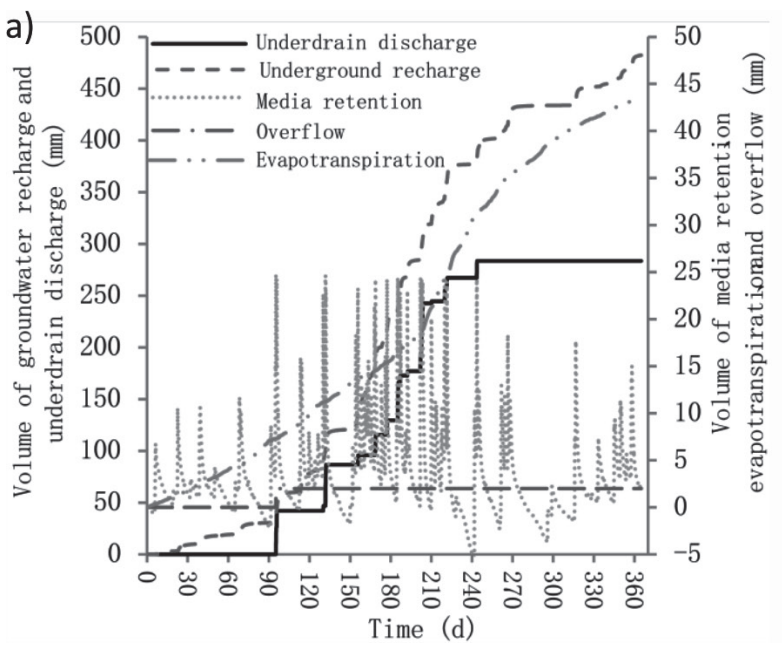

b)

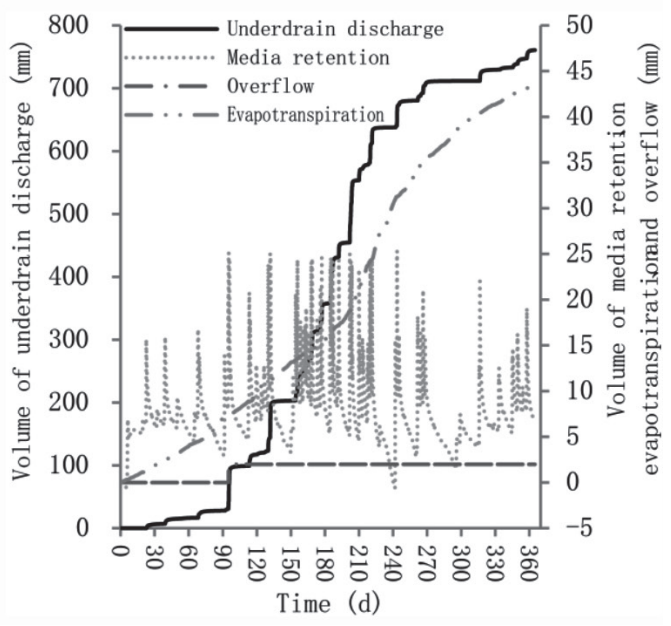

Fig. 4. The annual cumulative hydrographs of water balance elements of ZR and ZF: a) ZR, b) ZF. 


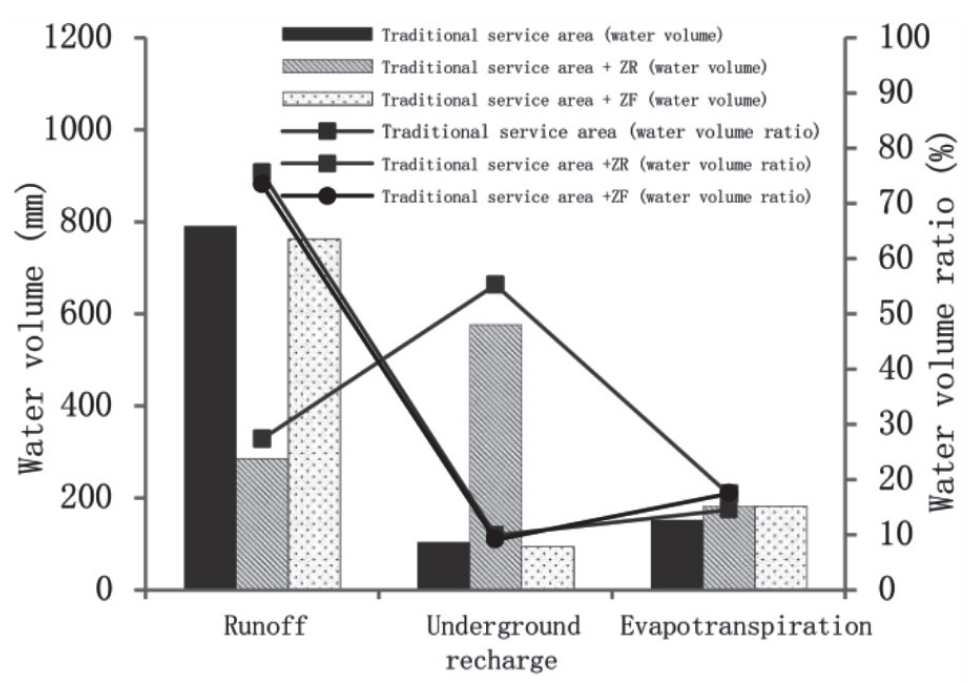

Hydrologic elements

Fig. 5. The influence of ZR and ZF on hydrology of expressway service area in 2010.

groundwater recharge and evapotranspiration accounts for less than $25 \%$, which not only destroys the original hydrological balance, but also causes the loss of a large number of rainwater resources.

Using ZR to treat rainwater runoff in the service area, the annual hydrological balance of the service area changes significantly, of which the runoff volume decreases from $790.1 \mathrm{~mm}$ to $285.54 \mathrm{~mm}$, decreasing by $48.21 \%$, the underground recharge volume increases from $103.6 \mathrm{~mm}$ to $576.44 \mathrm{~mm}$, increasing by $45.34 \%$, and the evapotranspiration volume increases from $151.7 \mathrm{~mm}$ to $181.34 \mathrm{~mm}$, increasing by $2.95 \%$. Therefore, for the service area with ZR, most of the runoff is consumed in the form of underground recharge and evapotranspiration, and the annual runoff control rate is effectively improved by $48.21 \%$, which plays a significant role in alleviating waterlogging, replenishing groundwater resources and improving the heat island effect in the service area. However, the influence of $\mathrm{ZF}$ on the hydrological balance of the service area is obviously insufficient. Since ZF limits the underground recharge, most of the rainwater is still discharged in the form of runoff, and the annual runoff volume is only reduced by $2.1 \%$. In practical application, the ZF should be combined with the reservoir, which can make the annual rainwater resource utilization rate reach $73.47 \%$, not only reducing the proportion of rainwater discharge, but also the water stored in the reservoir can be used for greening, car washing, flushing, cleaning, etc. in the service area.

\section{Regulation Effect of Bioretention on Annual Rainfall Events in Expressway Service Area}

\section{Analysis of Runoff Hydrograph of a Rainfall Event}

Taking the rainfall event on July 5 as an example, which is a Multi-peak rainfall event, with a rainfall of
$73.75 \mathrm{~mm}$, a rainfall duration of $32 \mathrm{~h}$, and a maximum rainfall peak of $16.91 \mathrm{~mm} / \mathrm{h}$, the runoff hydrographs of three types of service areas, namely, traditional, with $\mathrm{ZR}$, and with $\mathrm{ZF}$, are shown in Fig. 6. As can be seen from the figure, the runoff hydrograph of the traditional service area is significantly affected by the rainfall process. The flow fluctuates with the fluctuation of rainfall intensity, rising and falling sharply. The maximum runoff peak value is $15.95 \mathrm{~mm} / \mathrm{h}$, which is only reduced by $5.65 \%$, compared with the rainfall intensity of $16.91 \mathrm{~mm} / \mathrm{h}$, so the traditional service area has a limited ability to control the runoff of a single rainfall, and it is very easy to occur waterlogging in the service area due to excessive pressure on the rainwater pipe network during heavy rains. After setting ZF, the start time of runoff is significantly longer than that in the traditional service area, and the peak value of runoff is significantly reduced, with the maximum runoff peak value of $5.53 \mathrm{~mm} / \mathrm{h}$ and the peak reduction rate of $67.30 \%$. After setting $\mathrm{ZR}$, the start time of runoff has a more significant extension compared with the service area with $\mathrm{ZF}$, the first two runoff peaks can even be completely absorbed, with the maximum runoff peak of $4.85 \mathrm{~mm} / \mathrm{h}$ and the peak reduction rate of $71.28 \%$. The rainwater stored in the internal water storage area of ZR can completely or partially exfiltrate into the surrounding during the rainfall interval, so if the underdrain is to generate flow, the internal water storage area must be filled with water, thus leading to the enhanced control effect of ZR on rainfall. In addition, with the end of rainfall, the surface runoff in traditional service area is soon end, while the runoff of the service area with $\mathrm{ZR}$ and $\mathrm{ZF}$ have a significant extension trend, indicating that the bioretention can temporarily store the rainwater runoff and then release it slowly, which plays a significant role in relieving the drainage pressure of rainwater network during rainfall. 


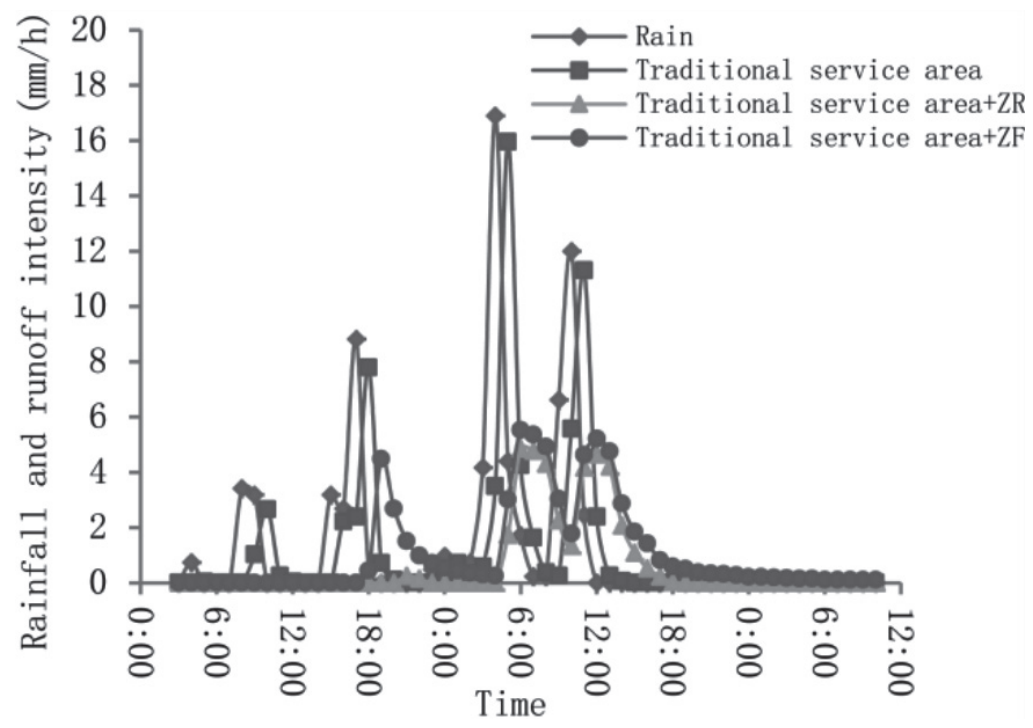

Fig. 6. Runoff hydrographs of three types of service areas, namely, traditional, with ZR, and with ZF for July 5, 2010 rainfall event.

\section{Analysis of Runoff Regulation Effect of Bioretention}

The regulation effect of bioretention on a single rainfall runoff can be described by three indicators: runoff reduction rate, runoff peak reduction rate, and runoff delay time, as shown in Equations 8, 9, and 10, respectively.

$$
\begin{gathered}
R_{V}=\frac{V_{\text {in }}-V_{\text {out }}}{V_{\text {in }}} \times 100 \% \\
R_{\text {peak }}=\frac{q_{\text {peak-in }}-q_{\text {peak-out }}}{q_{\text {peak-in }}} \times 100 \% \\
R_{\text {delay }}=t_{\text {out }}-t_{\text {in }}
\end{gathered}
$$

where $V_{\text {in }}$ is the runoff volume (mm); $V_{\text {out }}$ is the bioretention outflow volume, including overflow and underdrain discharge $(\mathrm{mm}) ; R_{V}$ is the runoff reduction rate $(\%) ; q_{\text {peak-in }}$ is the runoff peak flow $(\mathrm{mm} / \mathrm{h})$; $q_{\text {peak-out }}$ is the bioretention outflow peak flow $(\mathrm{mm} / \mathrm{h})$; $R_{\text {peak }}$ is the runoff peak reduction rate $(\%) ; t_{\text {out }}$ is the time bioretention begins to outflow; $t_{\text {in }}$ is the time the runoff enters the bioretention; $R_{\text {delay }}$ is the runoff delay time $(\mathrm{h})$, when the rainwater runoff is completely absorbed, the runoff delay is taken as $24 \mathrm{~h}$.

The runoff reduction rate, runoff peak reduction rate and runoff delay of 113 rainfall events in 2010 are shown in Fig. 7(a), 7(b-c), respectively, for three types of service areas, namely, traditional, with ZR, and with ZF. According to the figures, for the traditional service area, 19 of 113 rainfall events do not produce runoff, and the minimum rainfall that producing runoff is about $1 \mathrm{~mm}$, and the ranges of runoff reduction rate, runoff peak reduction rate and runoff delay are
$6.23 \% \sim 100 \%, 0.57 \%-100 \%$, and $0.5-24 \mathrm{~h}$, respectively, with the average values of $59.45 \%, 57.17 \%$, and $5.19 \mathrm{~h}$, respectively.

After setting ZR in the service area, 95 rainfall events do not produce runoff, and the minimum rainfall producing runoff can reach about $20 \mathrm{~mm}$, and the ranges of runoff reduction rate, runoff peak reduction rate and runoff delay are $25.25 \% \sim 100 \%$, $58.9 \% \sim 100 \%$, and $1.5 \sim 24 \mathrm{~h}$, respectively, with the average values of $91.56 \%, 95.22 \%$, and $20.55 \mathrm{~h}$, respectively, while for service area with ZF, 68 rainfall events do not produce runoff, and the minimum rainfall producing runoff can reach about $5 \mathrm{~mm}$, and the ranges of runoff reduction rate, runoff peak reduction rate and runoff delay are $-5.60 \% \sim 100 \%, 28.4 \% \sim 100 \%$, and $1.5 \sim 24 \mathrm{~h}$, respectively, with the average values of $68.59 \%, 86.67 \%$, and 15.22 h,respectively.

For the service area with $\mathrm{ZR}$ and $\mathrm{ZF}$, the ability to control rainfall has been significantly improved, and most of the rainfall can be completely absorbed, and the performance of $\mathrm{ZR}$ is better than $\mathrm{ZF}$. For the service area with $\mathrm{ZF}$, although the control effects to most rainfall events are better than that of traditional service area, the runoff reduction rate of some rainfall are decreased, and the rainfall event on April 6 even shows a negative reduction rate. This is mainly due to the fact that when the rainfall interval is short, the bioretention outflow caused by the previous rainfall has not completely ended, which has a certain impact on the outflow in the next rainfall event.

\section{Correlation Analysis of Runoff Characteristics and Rainfall Characteristics for Service Area}

Pearson correlation analysis was conducted on runoff characteristics (including runoff, runoff peak value and runoff delay time) and rainfall characteristics (including 
a) Traditional service area (runoff volume)

$\longrightarrow$ Traditional service area $+Z F$ (runoff volume)
$\longrightarrow$ Traditional service area $+Z R$ (runoff volume reduction rate) $\longrightarrow$ Traditional service area (runoff volume reduction rate)
$\longrightarrow$

Traditional service area + ZR (runoff volume)

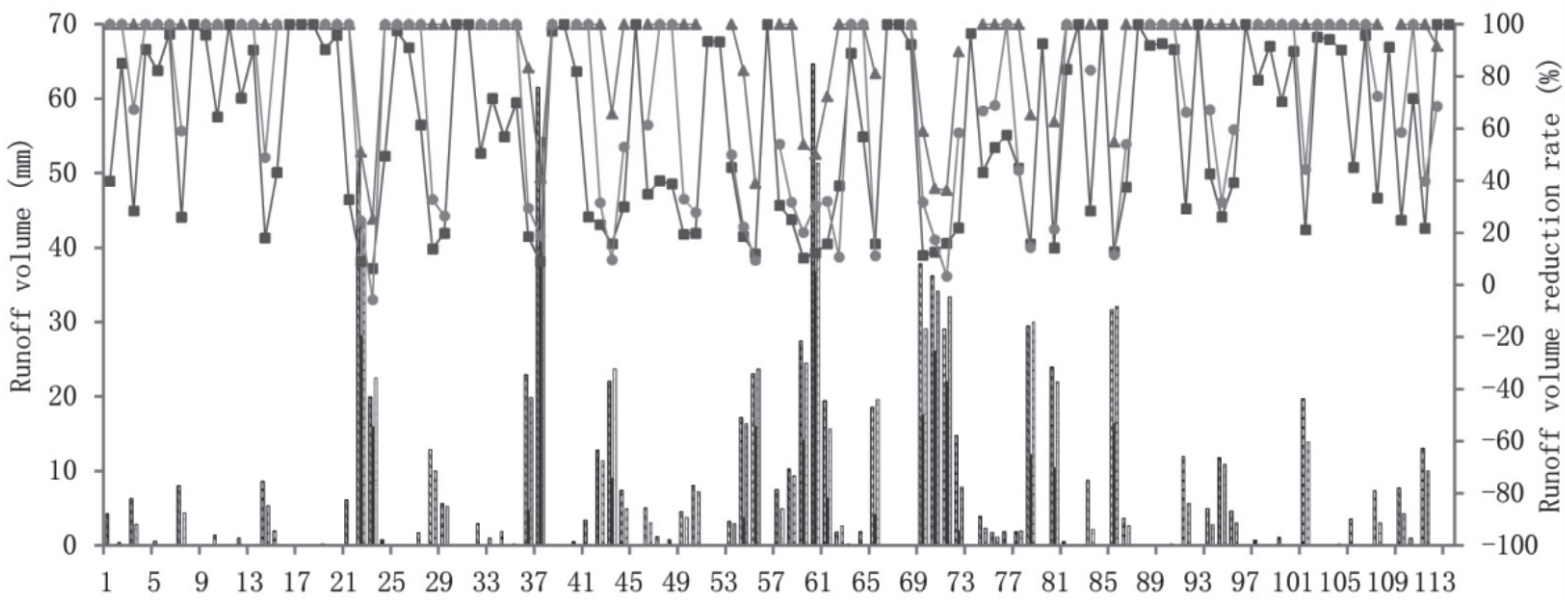

Rain number

b) Traditional service area (runoff peak)

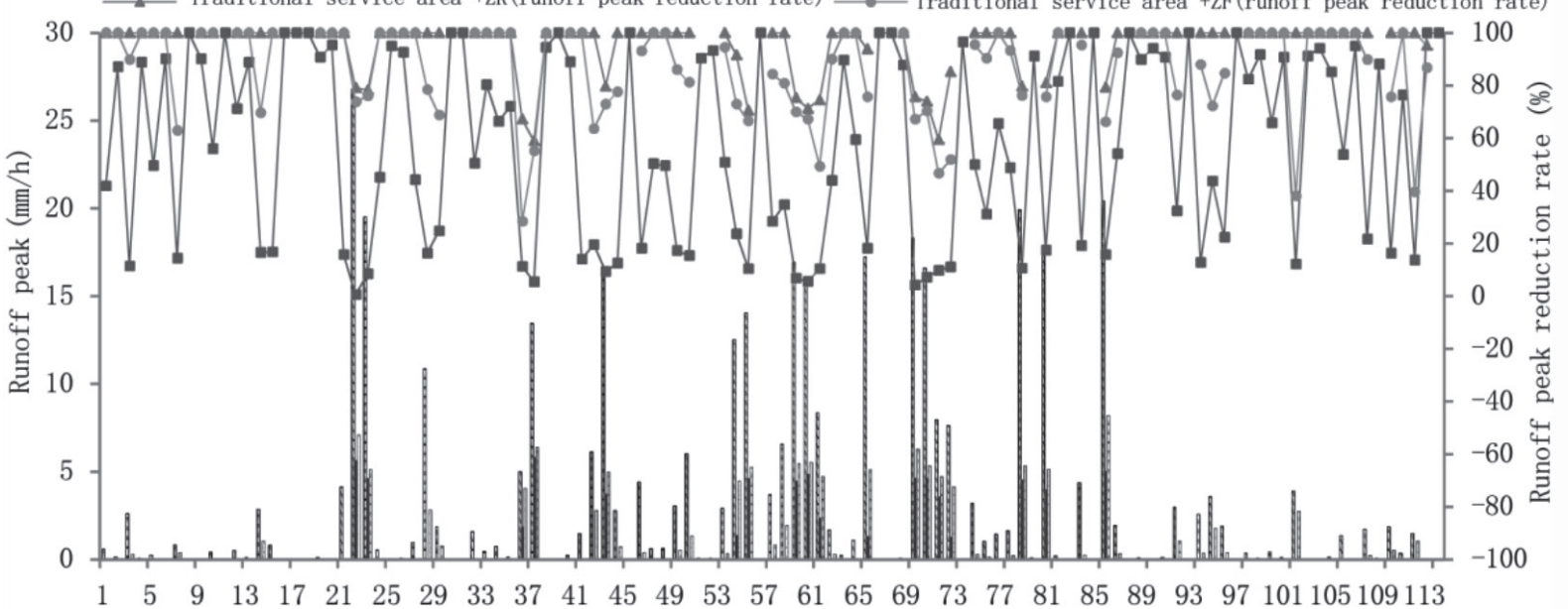

Rain number

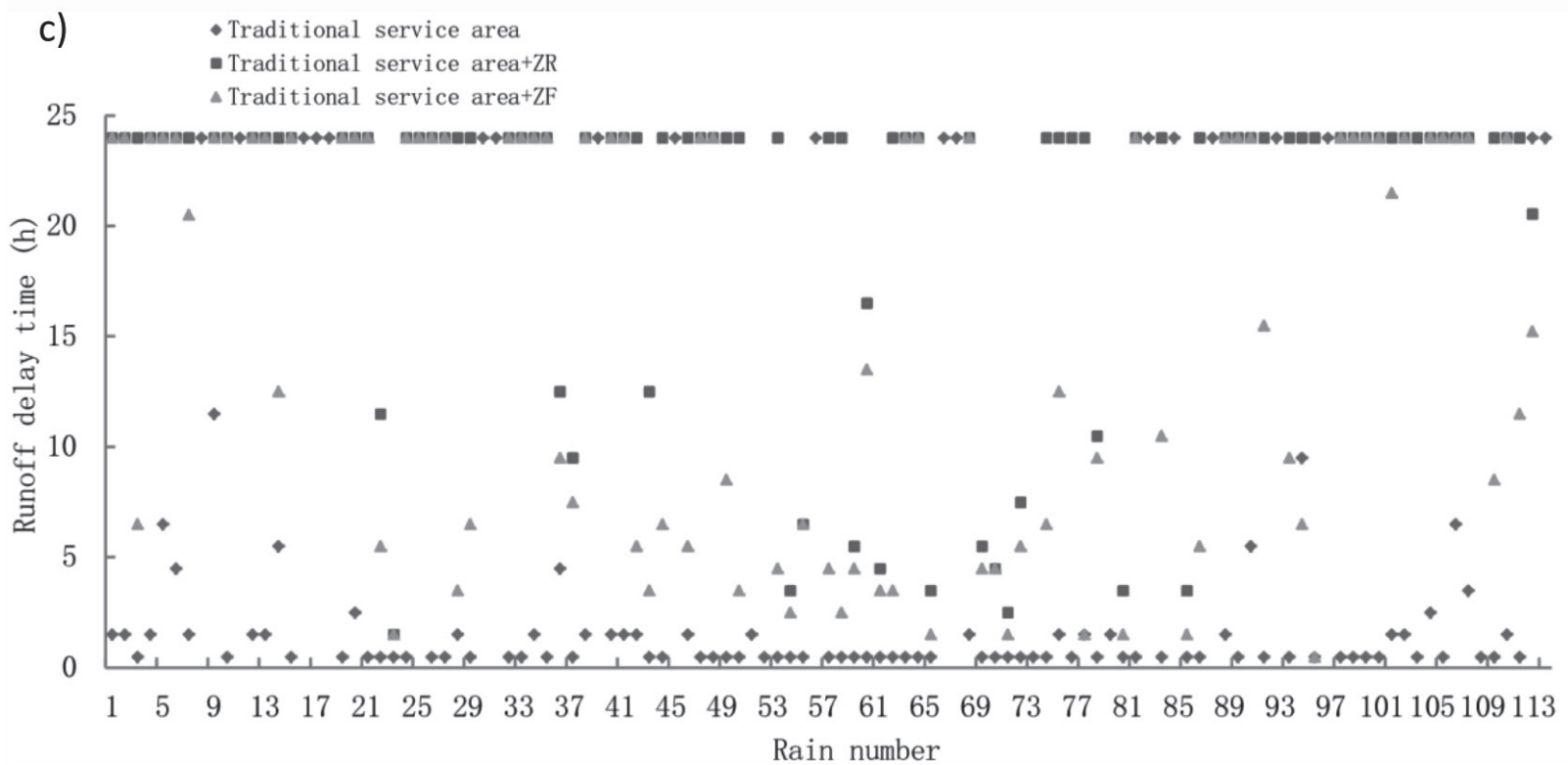

Fig. 7. Runoff regulation effect of three types of service areas, namely, traditional, with ZR, and with ZF for 113 rainfall events in 2010 : a) runoff reduction, b) runoff peak reduction, and c) runoff delay time. 
Table 3. Correlation coefficient and $\mathrm{P}$ value of rainfall characteristics and runoff characteristics in expressway service area.

\begin{tabular}{|c|c|c|c|c|c|c|}
\hline \multirow[b]{2}{*}{ Service area type } & \multirow{2}{*}{$\begin{array}{c}\text { Runoff } \\
\text { characteristics }\end{array}$} & \multicolumn{5}{|c|}{ Rainfall characteristics } \\
\hline & & $\begin{array}{l}\text { Rainfall } \\
(\mathrm{mm})\end{array}$ & $\begin{array}{l}\text { Rainfall duration } \\
\text { (h) }\end{array}$ & $\begin{array}{l}\text { Average rainfall } \\
\text { intensity }(\mathrm{mm} / \mathrm{h})\end{array}$ & $\begin{array}{l}\text { Maximum rainfall } \\
\text { intensity }(\mathrm{mm} / \mathrm{h})\end{array}$ & $\begin{array}{c}\text { Rainfall } \\
\text { interval (h) }\end{array}$ \\
\hline \multirow{6}{*}{$\begin{array}{l}\text { Traditional } \\
\text { service area }\end{array}$} & \multirow{2}{*}{$\begin{array}{c}\text { Runoff } \\
\text { volume (mm) }\end{array}$} & $\mathrm{R}=0.998$ & $\mathrm{R}=0.511$ & $\mathrm{R}=0.446$ & $\mathrm{R}=0.840$ & $\mathrm{R}=-0.098$ \\
\hline & & $\mathrm{P}<0.01$ & $\mathrm{P}<0.01$ & $\mathrm{P}<0.01$ & $\mathrm{P}<0.01$ & $\mathrm{P}=0.300$ \\
\hline & \multirow{2}{*}{$\begin{array}{c}\text { Runoff peak } \\
\text { value }(\mathrm{mm} / \mathrm{h})\end{array}$} & $\mathrm{R}=0.861$ & $\mathrm{R}=0.236$ & $R=0.669$ & $\mathrm{R}=0.992$ & $\mathrm{R}=-0.148$ \\
\hline & & $\mathrm{P}<0.01$ & $\mathrm{P}=0.012$ & $\mathrm{P}<0.01$ & $\mathrm{P}<0.01$ & $\mathrm{P}=0.118$ \\
\hline & \multirow{2}{*}{$\begin{array}{l}\text { Runoff delay } \\
\text { time } / \mathrm{h}\end{array}$} & $R=-0.321$ & $R=-0.256$ & $R=-0.249$ & $\mathrm{R}=0.333$ & $R=-0.150$ \\
\hline & & $\mathrm{P}<0.01$ & $\mathrm{P}<0.01$ & $\mathrm{P}<0.01$ & $\mathrm{P}<0.01$ & $\mathrm{P}=0.112$ \\
\hline \multirow{6}{*}{$\begin{array}{c}\text { Traditional } \\
\text { service area }+\mathrm{ZR}\end{array}$} & \multirow{2}{*}{$\begin{array}{c}\text { Runoff } \\
\text { volume (mm) }\end{array}$} & $\mathrm{R}=0.920$ & $\mathrm{R}=0.337$ & $\mathrm{R}=0.389$ & $\mathrm{R}=0.742$ & $\mathrm{R}=-0.140$ \\
\hline & & $\mathrm{P}<0.01$ & $\mathrm{P}<0.01$ & $\mathrm{P}<0.01$ & $\mathrm{P}<0.01$ & $\mathrm{P}=0.192$ \\
\hline & \multirow{2}{*}{$\begin{array}{c}\text { Runoff peak } \\
\text { value }(\mathrm{mm} / \mathrm{h})\end{array}$} & $\mathrm{R}=0.881$ & $\mathrm{R}=0.217$ & $\mathrm{R}=0.521$ & $\mathrm{R}=0.878$ & $\mathrm{R}=-0.197$ \\
\hline & & $\mathrm{P}<0.01$ & $\mathrm{P}=0.041$ & $\mathrm{P}<0.01$ & $\mathrm{P}<0.01$ & $\mathrm{P}=0.064$ \\
\hline & \multirow{2}{*}{$\begin{array}{l}\text { Runoff delay } \\
\text { time } / \mathrm{h}\end{array}$} & $R=-0.718$ & $R=-0.042$ & $R=-0.656$ & $R=-0.845$ & $\mathrm{R}=0.222$ \\
\hline & & $\mathrm{P}<0.01$ & $P=0.698$ & $\mathrm{P}<0.01$ & $\mathrm{P}<0.01$ & $\mathrm{P}=0.036$ \\
\hline \multirow{6}{*}{$\begin{array}{c}\text { Traditional } \\
\text { service area }+\mathrm{ZF}\end{array}$} & \multirow{2}{*}{$\begin{array}{c}\text { Runoff } \\
\text { volume (mm) }\end{array}$} & $\mathrm{R}=0.979$ & $\mathrm{R}=0.388$ & $\mathrm{R}=0.447$ & $\mathrm{R}=0.584$ & $R=-0.228$ \\
\hline & & $\mathrm{P}<0.01$ & $\mathrm{P}=<0.01$ & $\mathrm{P}<0.01$ & $\mathrm{P}<0.01$ & $\mathrm{P}=0.032$ \\
\hline & \multirow{2}{*}{$\begin{array}{c}\text { Runoff peak } \\
\text { value }(\mathrm{mm} / \mathrm{h})\end{array}$} & $\mathrm{R}=0.893$ & $\mathrm{R}=0.232$ & $\mathrm{R}=0.573$ & $\mathrm{R}=0.936$ & $R=-0.263$ \\
\hline & & $\mathrm{P}<0.01$ & $\mathrm{P}=0.03$ & $\mathrm{P}<0.01$ & $\mathrm{P}<0.01$ & $\mathrm{P}=0.013$ \\
\hline & \multirow{2}{*}{$\begin{array}{l}\text { Runoff delay } \\
\text { time } / \mathrm{h}\end{array}$} & $R=-0.556$ & $\mathrm{R}=0.011$ & $R=-0.538$ & $R=-0.686$ & $\mathrm{R}=0.397$ \\
\hline & & $\mathrm{P}<0.01$ & $P=0.918$ & $\mathrm{P}<0.01$ & $\mathrm{P}<0.01$ & $\mathrm{P}<0.01$ \\
\hline
\end{tabular}

rainfall, rainfall duration, average rainfall intensity, maximum rainfall intensity and rainfall interval) for three types of service areas, including traditional, with ZR, and with ZF, as shown in Table 3. As can be seen from the table, the runoff and runoff peak value of the three types of service areas are all positively correlated with rainfall, rainfall duration, average rainfall intensity and maximum rainfall intensity, and negatively correlated with rainfall interval, but the runoff delay time is on the contrary.

Among the runoff characteristics, the runoff of three types of service areas all have the strongest correlation and rainfall with the correlation coefficient $|R|>0.9$, reaching a very strong correlation level, followed by the maximum rainfall intensity with $|\mathrm{R}|=0.584 \sim 0.840$, reaching a medium level or above, but the correlations between runoff and average rainfall intensity and rainfall duration are both weak, basically reaching a medium or weak correlation level, and there is no correlation between runoff and rainfall interval. For the three types of service areas, the correlations between the runoff peak and the maximum rainfall intensity and rainfall are the strongest with $|\mathrm{R}|>0.8$, reaching a very strong correlation level, followed by the average rainfall intensity with $|\mathrm{R}|=0.521 \sim 0.669$, basically reaching a medium level, but the correlation between the runoff peak and the rainfall duration is weak, and there is basically no correlation between runoff peak and rainfall interval.

For the traditional service area, the correlations between runoff delay and all rainfall characteristics are poor, basically weak correlation or no correlation, while for the service area with $\mathrm{ZR}$ and $\mathrm{ZF}$, the correlation between runoff delay and maximum rainfall intensity reach a strong correlation level with $|\mathrm{R}|>0.6$, followed by the average rainfall intensity and rainfall with the correlation reaching a medium level, but there is basically weak correlation or no correlation between runoff delay and rainfall duration and rainfall interval.

\section{Conclusion}

The SWMM model was used to simulate the typical annual rainfall runoff in an expressway service area, and the long-term hydrologic performance of bioretention on the expressway service area was calculated using the VADOSE/W model, and the following conclusions were drawn:

The percentages of annual water balance elements of ZR, including underdrain discharge, underground recharge, overflow, evapotranspiration and soil 
retention, were $34.86 \%, 59.30 \%, 0.25 \%, 5.34 \%$ and $0.25 \%$, respectively, while which of ZF, including underdrain discharge, overflow, evapotranspiration, and soil retention, were $93.56 \%, 0.25 \%, 5.34 \%$ and $0.85 \%$, respectively. ZR could significantly reduce the runoff volume by increasing the underground recharge.

The annual hydrological balance of the service area changed significantly when ZR was used to treat the rainwater runoff, and the runoff was reduced by $48.21 \%$, the groundwater recharge was increased by $45.34 \%$, and the evapotranspiration was increased by $2.95 \%$, while the influence of ZF was obviously insufficient, and Meng [26] also showed that the water retention capability of bioretention with underdrains and impervious boundary was extremely limited. In practice, ZF should be combined with the reservoir to promote the reuse of rainwater resources.

For typical annual rainfall events, the average values of runoff reduction rate, runoff peak reduction rate and runoff delay of traditional service area were $59.45 \%$, $57.17 \%$ and $5.19 \mathrm{~h}$ respectively, while those of the service area with ZR and ZF were $91.56 \%, 95.22 \%$ and $20.55 \mathrm{~h}$ and $68.59 \%, 86.67 \%$ and $15.22 \mathrm{~h}$, respectively. The service area with ZR and ZF both could significantly improve the control ability of rainfall runoff, even completely absorb rainfall events with rainfall less than $20 \mathrm{~mm}$ and $5 \mathrm{~mm}$, and the performance of ZR was relatively better than ZF.

For three types of service areas, including traditional, with $\mathrm{ZR}$, and with $\mathrm{ZF}$, there was all a very strong positive correlation between runoff volume and rainfall, and the runoff peak had a very strong positive correlation with the maximum rainfall intensity and rainfall, but the correlation between runoff delay and rainfall characteristics was weak for the traditional service area, while the correlation between runoff delay and maximum rainfall intensity was strong negative for the service area with bioretention.

\section{Acknowledgments}

This work is supported by the National Natural Science Foundation of China (No. 51378520) and the National Natural Science Foundation of Chongqing (No. cstc2018jcyjAX0445).

\section{Conflict of Interest}

This manuscript has not been published or presented elsewhere in part or in entirety and is not under consideration by another journal. We have read and understood your journal's policies, and we believe that neither the manuscript nor the study violates any of these. There are no conflicts of interest to declare.

\section{References}

1. PROSPECTIVE INDUSTRY RESEARCH INSTITUTE, Analysis report of operations management and investment forecast on china highway service area (2021-2026), Forward Business Information Co., Ltd., Shenzhen, 2020 [In Chinese].

2. GAO J.P., PAN J.K., TANG R.Y., GUO S.S., LIU Y. LID facility layout and hydrologic impact simulation in an expressway service area. Polish Journal of Environmental Studies, 28 (6), 4153, 2019.

3. CHEN F., ZHANG H.Y., HU X.H., LIU H. Low impact development in sponge expressway service area based on storm water management model. Journal of Chongqing Jiaotong University (Natural Science), 38 (7), 54, 2019 [In Chinese].

4. KIM J.H., KANG H.M., KO S.O. Evaluation of pollutants concentrations and runoff characteristics in highway rest area. International journal of highway engineering, 12 (4), 131, 2010.

5. YE Y., XU P.B., ZHAI Y.B., CHEN L. Characterization of Highway Runoff Pollution. Environmental Science and Technology, 36 (6), 135, 2013 [In Chinese].

6. LIU Q.L. Rainwater control and utilization design for lowimpact development of expressway service area. Western China Communications Science and Technology, 4, 194, 2019 [In Chinese].

7. MACEDO M., LAGO C., MENDIONDO E.M. Stormwater volume reduction and water quality improvement by bioretention potentials and challenges for water security in a subtropical catchment. Archives of Pharmacal Research, 647, 923, 2019.

8. CHOWDHURY R., KSIKSI T., MOHAMED M.M.A., ABAYA J. Performance of vegetative bioretention system for greywater reuse in the arid climates. 8th International Conference on Environmental Science and Technology, Houston, United States of America, 2016.

9. MINISTRY OF HOUSING AND URBAN-RURAL CONSTRUCTION OF THE PEOPLE'S REPUBLIC OF CHINA. Technical guideline for sponge city construction: construction of rainwater system with low impact development (Trial). Beijing: Ministry of Housing and Construction Rural Development, 2014.

10. DAVIS A.P. Field performance of bioretention: hydrology impacts. Journal of Hydrologic Engineering, 13 (2), 90, 2008.

11. GAO J.P., PAN J.K., XIE Y.C. Effects of bioretention structural layer parameters on detention and retention for road runoff. Advances in Water Science, 28 (5), 702, 2017 [In Chinese].

12. LI J.K., JIANG C.B., ZHANG S.C., LI H.E. Pilot scale experiments and simulation of the purification effects of bioswale on urban road runoff. Advances in Water Science, 27 (6), 898, 2017 [In Chinese].

13. MUERDTER C., WONG C., LEFEVRE G.H. Emerging investigator series: the role of vegetation in bioretention for stormwater treatment in the built environment: pollutant removal, hydrologic function, and ancillary benefits. Environmental Science Water Research and Technology, 4 (5), 592, 2018.

14. DEBUSK K.M., HUNT W.F., LINE D.E. Bioretention outflow: does it mimic nonurban watershed shallow interflow? Journal of Hydrologic Engineering, 16 (3), 274, 2010. 
15. PAN G.Y., XIA J., ZHANG X., WANG H.P., LIU E.M. Research on simulation test of hydrological effect of bioretention units. Water Resources and power, 30 (5), 13, 2012.

16. WINSTON R.J., DORSEY J.D., HUNT W.F. Quantifying volume reduction and peak flow mitigation for three bioretention cells in clay soils in northeast Ohio. Science of the Total Environment, 553, 83, 2016.

17. XIA J, WANG H, STANFORD R.L., PAN G., YU S.L. Hydrologic and water quality performance of a laboratory scale bioretention unit. Frontiers of Environmental Science and Engineering, 12 (1), 14, 2018.

18. GULBAZ S., KAZEZYILMAZ-ALHAN C.M. Experimental investigation on hydrologic performance of LID with rainfall-watershed-bioretention system. Journal of Hydrologic Engineering, 22 (1), D4016003, 2016.

19. LI M.H., SWAPP M., KIM M.H., CHU K.H., CHAN Y.S. Comparing bioretention designs with and without an internal water storage layer for treating highway runoff. Water Environment Research, 86 (5), 387, 2014.

20. GAO J.P., PAN J.K, HU N. XIE C.C. Hydrologic performance of bioretention in an expressway service area. Water Science and Technology A Journal of the International Association on Water Pollution Research, 77 (7), 1829, 2018.

21. LIU R., FASSMAN-BECK E. Hydrologic response of engineered media in living roofs and bioretention to large rainfalls: experiments and modeling. Hydrological Processes, 31 (3), 556, 2017.

22. SHAFIQUE M.A. Review of the bioretention system for sustainable storm water management in urban areas. Materials and Geoenvironment, 63 (4), 227, 2016.

23. TAHVONEN O. Adapting bioretention construction details to local practices in Finland. Sustainability, 10 (2), 276, 2018.

24. STEWART R.D., LEE J.G., SHUSTER W., DARNER R.A. Modeling hydrological response to a fully-monitored urban bioretention cell. Hydrological Processes, 10.1002/ hyp.11386, 2017.
25. BOANCA P.L., DUMITRAS A., LUCA L., BORSOPRISA S. Analysing bioretention hydraulics and runoff retention through numerical modelling using RECARGA: a case study in a romanian urban area. Polish Journal of Environmental Studies, 27 (5), 1965, 2018.

26. MENG Y.Y., WANG H.X., CHEN J.G., ZHANG S.H. Modelling hydrology of a single bioretention system with HYDRUS-1D. The Scientific World Journal, 10.1155/2014/521047, 2014.

27. CHEN T., LI Y., CAO K.L. Application of SUSTAIN to evaluate runoff control effect of LID practices in a residential area. China Water and Wastewater, 32 (9), 144, 2016 [In Chinese].

28. ZHANG W., SUN C., QIU Q. Characterizing of a capillary barrier evapotranspirative cover under high precipitation conditions. Environmental Earth Sciences, 75 (6), 513, 2016.

29. ROSSMAN, L.A. Storm water management model User's manual (version 5.0), U.S. Environmental Protection Agency, Cincinnati, OH, 2010.

30. XU P., HE J.C., REN X.X., TANG W.Z, ZHANG Y.J., HUANG J.J. Optimization of LID design parameters of urban road based on SWMM model. Water Resources and Power, 34 (2), 21, 2016 [In Chinese].

31. WANG W.W., ZHAO Z.J., QIN H.P. Hydrological effect assessment of low impact development for urbanized area based on SWMM. Acta Scientiarum Naturalium Universitatis Pekinensis, 48 (2), 303, 2012 [In Chinese].

32. LIU X.P. Parameter calibration method for urban rainfallrunoff model based on runoff coefficient. Water \& Wastewater Engineering, 35 (11), 213, 2009 [In Chinese].

33. JIAO Y.H., JIANG L.Q. Study of the effects on evapotranspiration to long-term stability of slope. Site Investigation Science and Technology, 5, 3, 2009 [In Chinese].

34. ZHUANG D.W., KONG B., WANG X.Q., SUN X.W. Study on leaf area index of lawn and ground cover plants. Shandong Forestry Science and Technology, 44 (2), 72, 2014 [In Chinese]. 